\title{
Intercomparison of a Cavity Attenuated Phase Shift-based extinction monitor (CAPS PMex) with an integrating nephelometer and a filter-based absorption monitor
}

\author{
A. Petzold ${ }^{1, *}$, T. Onasch ${ }^{2}$, P. Kebabian ${ }^{2}$, and A. Freedman ${ }^{2}$ \\ ${ }^{1}$ Forschungszentrum Jülich GmbH, Institut für Energie- und Klimaforschung IEK-8: Troposphäre, 52425 Jülich, Germany \\ 2 Aerodyne Research Inc., 45 Manning Road, Billerica, MA 01821-3976, USA \\ *formerly at: Deutsches Zentrum für Luft- und Raumfahrt, 82234 Oberpfaffehofen, Germany
}

Correspondence to: A. Petzold (a.petzold@fz-juelich.de)

Received: 23 September 2012 - Published in Atmos. Meas. Tech. Discuss.: 17 October 2012

Revised: 22 March 2013 - Accepted: 9 April 2013 - Published: 3 May 2013

\begin{abstract}
An evaluation of the Cavity Attenuated Phase Shift particle light extinction monitor (CAPS PM $\mathrm{ex}_{\mathrm{ex}}$ ) using a combination of a 3-wavelength Integrating Nephelometer (NEPH) and a 3-wavelength filter-based Particle Soot Absorption Photometer (PSAP) was carried out using both laboratory-generated test particles and ambient aerosols. An accurate determination of a fixed pathlength correction for the CAPS $\mathrm{PM}_{\mathrm{ex}}$ was made by comparing extinction measurements using monodisperse PSL spheres in combination with Mie scattering calculations to account for the presence of PSL conglomerates. These studies yielded a linear instrument response over the investigated dynamical range from 20 to $450 \mathrm{Mm}^{-1}\left(10^{-6} \mathrm{~m}^{-1}\right)$ with a linear correlation coefficient of $R^{2}>0.98$. The adjustment factor was determined to be 1.05 times that previously reported. Correlating CAPS extinction to extinction measured by the NEPH + PSAP combination using laboratory-generated polydisperse mixtures of purely scattering ammonium sulfate and highly absorbing black carbon provided a linear regression line with slope $m=1.00\left(R^{2}=0.994\right)$ for single-scattering albedo values $(\lambda=630 \mathrm{~nm})$ ranging from 0.35 (black carbon) to 1.00 (ammonium sulfate). For ambient aerosol, light extinction measured by CAPS was highly correlated $\left(R^{2}=0.995\right)$ to extinction measured by the NEPH + PSAP combination with slope $m=0.95$.
\end{abstract}

\section{Introduction}

The in situ measurement of atmospheric aerosol optical properties is an important component of quantifying climate change (Solomon et al., 2007; Schwartz et al., 2010). In particular, in situ measurement of the aerosol single-scattering albedo (SSA), which is the ratio of aerosol scattering to aerosol extinction, is identified as a key challenge in atmospheric sciences and climate change research (Loeb and $\mathrm{Su}$, 2010). Ideally, the complete set of aerosol optical properties are measured through optical closure studies which simultaneously measure aerosol extinction, scattering and absorption coefficients. The recent development of new optical instruments have made real-time in situ optical closure studies attainable, including from mobile platforms such as aircraft (Langridge et al., 2011); however, many of these instruments are state-of-the-art and not practical for routine monitoring. Here, we evaluate the recently developed Cavity Attenuated Phase Shift particle light extinction monitor (CAPS $\mathrm{PM}_{\mathrm{ex}}$ ) against commonly used techniques for routine monitoring of aerosol optical properties.

Aerosol extinction, scattering and absorption coefficients are measured using different techniques. The particle scattering coefficient $\sigma_{\mathrm{sp}}$ is typically measured by an Integrating Nephelometer (Heintzenberg et al., 2006). For the particle absorption coefficient $\sigma_{\text {ap }}$, either filter-based or in situ methods are available, both of which have been extensively investigated in various studies (Arnott et al., 2003; Sheridan et al., 2005; Müller et al., 2011). In the laboratory, the direct measurement of the particle extinction coefficient $\sigma_{\mathrm{ep}}$ 
is performed with long-path extinction cells (Schnaiter et al., 2005) or cavity ring-down systems (Strawa et al., 2003), while various methods exist for atmospheric measurements (Schmid et al., 2006).

Long-path extinction cells are limited in their lower detection range to extinction coefficients well above $10 \mathrm{Mm}^{-1}$; e.g. both Schnaiter et al. (2005) and Chartier and Greenslade (2012) report for their long-path extinction spectrometers noise levels of $20 \mathrm{Mm}^{-1}$ for extinction cells of optical path length of $10 \mathrm{~m}$ and $\sim 20 \mathrm{~m}$ respectively and for integration times of several minutes. According to the underlying Lambert-Beer law, an improvement of the lower detection limit can be achieved only by increasing the optical path length which, however, imposes geometrical limitations. In contrast to long-path extinction cells, the cavity ring-down (CRD) method yields the aerosol extinction coefficient by measuring the time constant for light decay in a high-finesse cavity containing the absorbing and scattering particles. A detailed introduction to the CRD technique for aerosol extinction measurement is given by Strawa et al. (2003), whereas Moosmüller et al. (2005) provide an overview over the various CRD and cavity-enhanced detection approaches. Driven by a rapid technology development, CRD instruments are now available as multi-wavelength systems for atmospheric measurements (Schmid et al., 2006; Baynard et al., 2007; Atkinson et al., 2010) and laboratory studies (Sheridan et al., 2005; Butler et al., 2009; Cross et al., 2010).

Recently, a compact and robust family of optical instruments based on the cavity attenuated phase shift technique has become available (Kebabian et al., 2007). In particular, the CAPS $\mathrm{PM}_{\mathrm{ex}}$ particle optical extinction monitor has demonstrated sensitivity $(2-\sigma)$ of less than $2 \mathrm{Mm}^{-1}$ in $1 \mathrm{~s}$ sampling period; with a $60 \mathrm{~s}$ averaging time, a detection limit of less than $0.3 \mathrm{Mm}^{-1}$ can be achieved. The CAPS PM $\mathrm{ex}_{\mathrm{x}}$ technique, similar in its basic principle to cavity ring-down, relies on the use of a short $(26 \mathrm{~cm})$ sample cell employing high reflectivity mirrors (Kebabian and Freedman, 2007; Kebabian et al., 2007). Square-wave modulated light emitted from a light emitting diode (LED) at a wavelength $\sim 630 \mathrm{~nm}$ is directed through one mirror into the sample cell. The distortion in the square wave caused by the effective optical path length within the cavity (approx. $2 \mathrm{~km}$ light path) is measured as a phase shift in the signal as detected by a vacuum photodiode, which is located behind the second mirror. A detailed description of the method, including first results from laboratory characterization and field deployment, is given by Massoli et al. (2010), while Yu et al. (2011) reports an application to the direct measurement of combustion particle emissions from aircraft engines.

This study characterizes the CAPS $\mathrm{PM}_{\mathrm{ex}}$ instrument for both laboratory test aerosols and ambient aerosol. The CAPS $\mathrm{PM}_{\mathrm{ex}}$ instrument was evaluated against a combination of an integrating nephelometer (NEPH; TSI Model 3563), a particle soot absorption photometer (PSAP; Radiance Research)

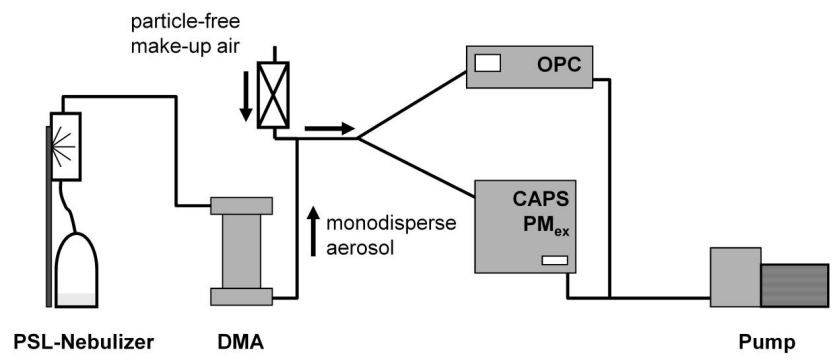

Fig. 1. Experimental set-up for the pathlength adjustment of the CAPS $\mathrm{PM}_{\mathrm{ex}}$ with monodisperse PSL spheres.

(Virkkula et al., 2005) and a multi-angle absorption photometer (MAAP; Thermo Model 5012) (Petzold and Schönlinner, 2004; Petzold et al., 2005).

The experimental approach taken for the evaluation of the CAPS $\mathrm{PM}_{\mathrm{ex}}$ extinction monitor was divided into three consecutive steps: (1) an accurate determination of instrument pathlength adjustment by using non-absorbing polystyrene latex (PSL) spheres combined with Mie theory calculations; (2) instrument intercomparison with polydisperse laboratory aerosols of known composition; and (3) instrument intercomparison for ambient aerosol.

\section{Experimental section}

\subsection{Instrumental set-up}

Instruments deployed in our study were the CAPS PM $\mathrm{Px}_{\mathrm{ex}}$ extinction monitor for measuring the particle extinction coefficient, $\sigma_{\mathrm{ep}}$, the PSAP and MAAP instruments for measuring the particle absorption coefficient, $\sigma_{\mathrm{ap}}$, and a NEPH for measuring the particle scattering coefficient, $\sigma_{\mathrm{sp}}$. Instrument details and acronyms used in this publication are summarized in Table 1.

Monodisperse particle distributions of PSL spheres (Duke Scientific Corp., Palo Alto, CA) of nominal diameters $350 \pm 7,499 \pm 5,596 \pm 6,701 \pm 6$, and $903 \pm 9 \mathrm{~nm}$ were nebulized in a Collison-type atomizer (Massoli et al., 2010), dried to $\leq 25 \%$ relative humidity (RH) in a tube filled with silica gel, size-selected by a differential mobility analyzer and fed into the CAPS $\mathrm{PM}_{\mathrm{ex}}$ extinction monitor. The total number concentration, $N_{\text {total }}$, and the size distribution of the PSL spheres were measured simultaneously by an optical particle counter (OPC) (Grimm Model 1.129), which has a lower detection size limit of $250 \mathrm{~nm}$ in diameter for a particle refractive index of 1.585. The experimental set-up used for the instrument calibration is shown in Fig. 1.

Polydisperse test aerosols were generated in a laboratory setting with varying SSA values ranging from 0.35 to 1.0 at a wavelength of $630 \mathrm{~nm}$ by mixing purely scattering ammonium sulfate (AS) particles with strongly absorbing black carbon (BC) aerosol (Regal 400R pigment black, 
Table 1. Instruments used during the evaluation experiments.

\begin{tabular}{|c|c|c|c|c|c|c|}
\hline Instrument and Manufacturer & Acronym & Property & Wavelength, nm & $\begin{array}{r}\text { Time } \\
\text { resolution }\end{array}$ & $\begin{array}{r}\text { Flow, } \\
\mathrm{L} \mathrm{min}^{-1}\end{array}$ & Reference \\
\hline $\begin{array}{l}\text { Cavity Attenuated Phase Shift } \\
\text { Aerodyne Res. Inc., USA }\end{array}$ & CAPS PM ex $_{1}$ & extinction & 630 & $1 \mathrm{~s}$ & 1.0 & Massoli et al. (2010) \\
\hline $\begin{array}{l}3 \lambda \text {-Integrating Nephelometer } \\
\text { TSI Model 3563, USA }\end{array}$ & $\mathrm{NEPH}$ & scattering & $450,550,700$ & $10 \mathrm{~s}$ & 11.0 & Anderson and Ogren (1998) \\
\hline 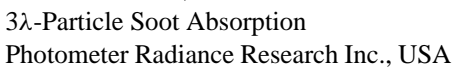 & PSAP & absorption & $467,530,660$ & $1 \mathrm{~s}$ & 0.95 & $\begin{array}{l}\text { Bond et al. (1999); } \\
\text { Virkkula et al. (2005) }\end{array}$ \\
\hline $\begin{array}{l}\text { Multi-Angle Absorption } \\
\text { Photometer Thermo Model 5012, USA }\end{array}$ & MAAP & absorption & 637 & $60 \mathrm{~s}$ & 8.0 & $\begin{array}{l}\text { Petzold and Schönlinner (2004); } \\
\text { Müller et al. (2011) }\end{array}$ \\
\hline $\begin{array}{l}\text { Optical Particle Counter } \\
\text { GRIMM Model } 1.129, \text { Germany }\end{array}$ & $\mathrm{OPC}$ & $\begin{array}{l}\text { size } \\
\text { distribution }\end{array}$ & 670 & $6 \mathrm{~s}$ & 1.2 & \\
\hline
\end{tabular}

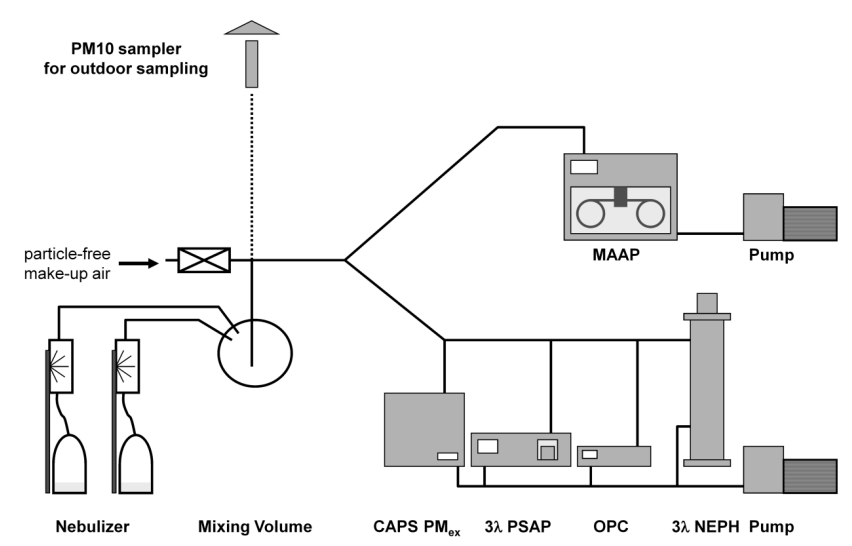

Fig. 2. Experimental set-up for the instrument evaluation using polydisperse aerosol mixtures of black carbon and ammonium sulfate; the sampling line was switched to the outdoor $\mathrm{PM}_{10}$ sampler (dashed line), for measuring ambient aerosol.

Cabot Corp.). Both types of aerosols were generated by nebulizing a solution of the respective substance in deionized water in an atomizer and drying the aerosol as described above. When generating external aerosol mixtures, the pure aerosols were fed into a $3 \mathrm{~L}$ mixing volume from which the instruments sampled. Particle-free make-up air was added downstream of the mixing volume to balance the input flow from the atomizers and the overall flow sampled by the suit of instruments. The set-up used for the polydisperse laboratory aerosol studies is shown schematically in Fig. 2.

Test aerosol runs were performed consecutively for five concentration levels of AS, four concentration levels of pure $\mathrm{BC}$ and three levels of $\mathrm{AS}+\mathrm{BC}$ mixtures. For both the $\mathrm{BC}$ and the AS aerosol, the atomizers were operated at constant conditions for high output, while lower values of the extinction coefficient were achieved by adding particle-free dilution air. The dilution air flow was adjusted such that the measurements spanned over more than one order of magnitude for $\sigma_{\mathrm{ep}}$ with values ranging from 30 to $400 \mathrm{Mm}^{-1}$. Mixed aerosols were generated by keeping a $\mathrm{BC}$ aerosol concentration constant and adding AS aerosol so that the obtained SSA values at a wavelength of $630 \mathrm{~nm}$ ranged from 0.8 to 1.00 for the mixed AS + BC aerosols. Test aerosols thus covered the entire range of SSA values relevant for ambient aerosol measurements (0.4 to 1.0$)$.

For the measurement of ambient aerosol, the instrumental set-up shown in Fig. 2 was kept unchanged, but the sampling line was switched from the aerosol generator branch to the $\mathrm{PM}_{10}$ sampling line. The $\mathrm{PM}_{10}$ sampler was installed on the roof of the Aerodyne building, which is located in Billerica, MA, in a business park about $200 \mathrm{~m}$ east of Route 3. Ambient aerosol sampling was conducted continuously over a period of two weeks from 27 May to 8 June 2011.

For both types of studies, the sample lines were approximately equal in length for both instruments and as short as possible (in general $<1 \mathrm{~m}$ ), and the flows at bifurcations were designed to be nearly equal. Considered particle diameters for line loss estimates ranged from $0.1 \mu \mathrm{m}$ (the lower limit of the optical activity of particles at visible wavelengths) to approx. $1 \mu \mathrm{m}$. Line loss estimates were performed based on Hinds (1999) and AEROCALC (P. Baron, personal website, 2001).

During the pathlength adjustment studies (see Fig. 1), both the CAPS PM $\mathrm{ex}_{\mathrm{ex}}$ and OPC were sampling with an approximate flow of $1 \mathrm{Lpm}$, and the tubing lengths downstream of the bifurcation were approx. $1 \mathrm{~m}$ each. Thus, for these studies any particle loss effects will be of equal magnitude for both instruments.

All key instruments for the aerosol mixture studies were connected to the same branch downstream of the $45^{\circ}$ angular split from the MAAP (see Fig. 2 for details). This flow was then divided between the NEPH $(11 \mathrm{Lpm})$ and the other instruments (in total, $3 \mathrm{Lpm}$ ). Line loss estimates started with the flow split for the NEPH line as upper limit estimate and considered line length of $1 \mathrm{~m}$, flow of $11 \mathrm{Lpm}$, and velocity of $2.5 \mathrm{~m} \mathrm{~s}^{-1}$. For particles of $100 \mathrm{~nm}$ in diameter we found diffusion loss $<1 \%$ and inertia loss at bends of $45^{\circ}<1 \%$, whereas losses by gravitational settling were negligible for sizes from 0.1 to $1 \mu \mathrm{m}$ in diameter. From this estimate we conclude that particle losses due to inertial and diffusional 

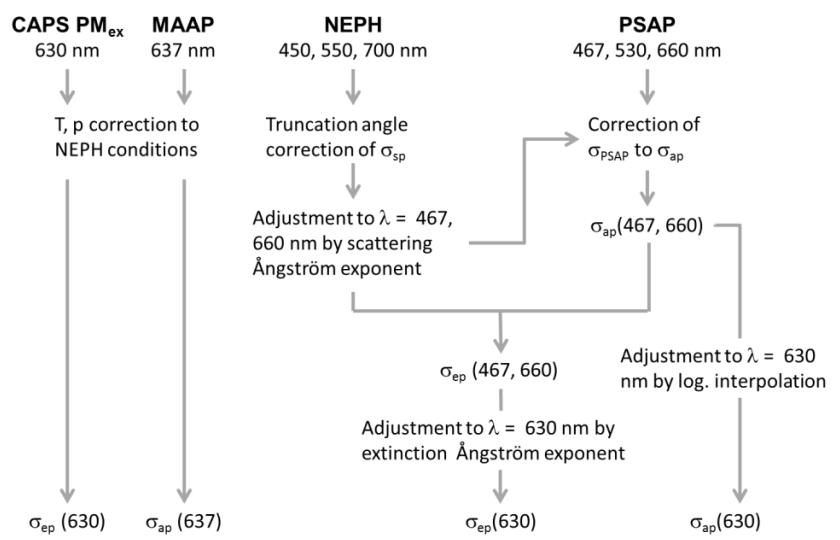

Fig. 3. Schematic of the data inversion procedures for the optical instruments.

processes are of the order of $1 \%$ and can therefore be neglected in our data analysis.

Instrument precision was determined by operating two identical CAPS PM $_{\mathrm{ex}}$ instruments side by side in the Aerodyne laboratories for $48 \mathrm{~h}$. The instruments were sampling laboratory air, which was relatively well temperaturecontrolled and reasonably dry because of the air conditioning of the laboratory. Although we used two CAPS PM $\mathrm{ex}_{\mathrm{e}}$ instruments equipped for a wavelength of $530 \mathrm{~nm}$, we decided to include these data in the instrument evaluation because instrument reproducibility is expected to be independent of the operation wavelength.

\subsection{Data inversion}

NEPH data were corrected for truncation angle effects by two approaches: the correction proposed by Anderson and Ogren (1998) for mostly scattering aerosol was applied to AS runs, mixed $\mathrm{AS}+\mathrm{BC}$ runs and ambient aerosol data, while for highly absorbing $\mathrm{BC}$ aerosols, the approach suggested by Massoli et al. (2009) was used. Both correction schemes are based on the measured light scattering Ångström exponent $\stackrel{\circ}{\text { sp }}=-\log \left(\sigma_{\mathrm{sp} .450} / \sigma_{\mathrm{sp} .700}\right) / \log (450 / 700)$; see Massoli et al. (2009) for details. Further adjustment of $\sigma_{\mathrm{sp}}$ to the PSAP operation wavelengths of 467 and $660 \mathrm{~nm}$ was performed using the measured value of $\mathrm{a}_{\text {sp. }}$. The wavelength of $550 \mathrm{~nm}$ was not used in this study.

The PSAP raw signal was corrected according to Virkkula et al. (2005), Virkkula (2010) and Ogren (2010) using the NEPH data. PSAP data measured at filter transmissions $<70 \%$ were rejected, as recommended by Bond et al. (1999). MAAP and CAPS $\mathrm{PM}_{\mathrm{ex}}$ data were used without further corrections except the adjustment to temperature and pressure measured by the NEPH, i.e. all data refer to same pressure and temperature conditions. This approach is justified because a $5 \mathrm{~K}$ heating of the NEPH by the lamp at constant pressure and an ambient temperature of approximately $300 \mathrm{~K}$ would result in an overestimation of $\sigma_{\text {ap }}$ by $1.5 \%$.
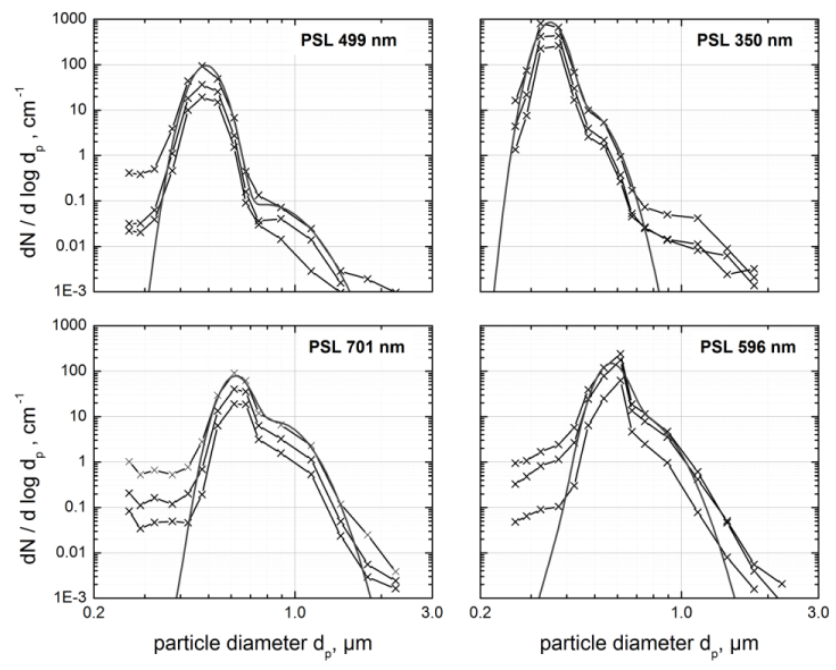

Fig. 4. Number size distributions of PSL spheres measured downstream of the DMA; grey lines represent bimodal log-normal size distributions representing PSL and PSL conglomerates. Nominal sizes of atomized PSL standards are indicated.

Since the internal temperature of the PSAP is not available, we decided to neglect this correction.

Data from CAPS PM $\mathrm{ex}_{\mathrm{e}}$ and from NEPH + PSAP were processed on the basis of the NEPH time resolution of $10 \mathrm{~s}$, whereas MAAP data are reported on a $1 \mathrm{~min}$ time resolution. For the final evaluation of instrument performances for ambient aerosol, all instrument data were converted to $10 \mathrm{~min}$ time averages.

For instrument intercomparison purposes, all instruments were adjusted to the wavelength of $630 \mathrm{~nm}$. Data were compared in the red spectral region since both singlewavelength instruments (CAPS $\mathrm{PM}_{\mathrm{ex}}$ and MAAP) operate at $\lambda \cong 630 \mathrm{~nm}$, whereas the 3 -wavelength instruments NEPH and PSAP allow for a wavelength-dependent adjustment based on direct measurement. The value for $\sigma_{\mathrm{ep}}$ from NEPH + PSAP was adjusted to that for $630 \mathrm{~nm}$ by using the extinction Ångström exponent measured for the wavelength pair $467 \mathrm{~nm} / 660 \mathrm{~nm}$, and the value for $\sigma_{\text {ap }}$ was adjusted to $630 \mathrm{~nm}$ by logarithmic interpolation. Figure 3 summarizes the data inversion schemes applied to the various instruments.

\section{Results}

\subsection{Determination of pathlength adjustment}

The CAPS $\mathrm{PM}_{\mathrm{ex}}$ extinction monitor provides an absolute measurement of particle light extinction. However, in order to keep the mirrors from being contaminated by the particles, a small volume in front of each mirror must be flooded with particle-free purge gas, thus shortening the effective pathlength. As noted in Massoli et al. (2010), this effect was 


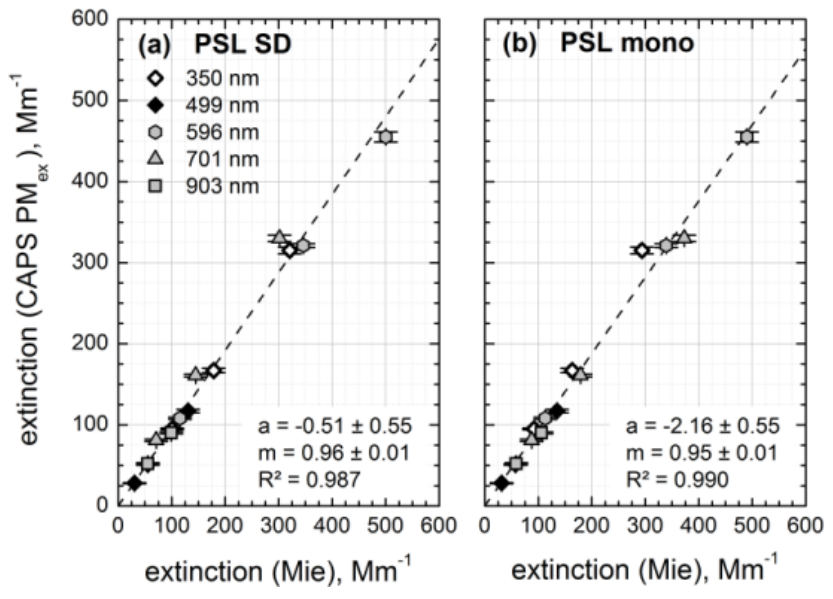

Fig. 5. Comparison of extinction at a wavelength of $630 \mathrm{~nm}$ measured by the CAPS $\mathrm{PM}_{\mathrm{ex}}$ instrument (y-axis) and extinction calculated for PSL spheres using the full size distribution information (a) and assuming monodisperse spheres at the nominal diameter (b).

approximately measured using nitrogen dioxide, an absorbing gas. When extinction measurements using PSL spheres were compared to Mie scattering cross sections calculated assuming a monodisperse size distribution, the results were within the $\pm 10 \%$ uncertainty of the condensation particle counter used to measure particle concentration.

In the present study, we measured the pathlength adjustment using PSL particles and Mie theory. The actual PSL size distributions were measured by means of an optical particle counter. The measured size distributions were parameterized as bi-modal log-normal size distributions with geometric mean diameters $d_{\mathrm{g} 1}$ and $d_{\mathrm{g} 2}$ and geometric standard deviations $\sigma_{\mathrm{g} 1}$ and $\sigma_{\mathrm{g} 2}$, which then served as input to the Mie code. The number concentrations of the two log-normal modes $N($ mode 1$)$ and $N(\operatorname{mode} 2)$ were normalized to $N_{\text {total }}$ so that $N_{1}+N_{2}=1$ with $N_{1}=N$ (mode $1) / N_{\text {total }}$ and $N_{2}=N($ mode 2$) / N_{\text {total }}$. Single-particle extinction cross sections for the polydisperse case were then calculated as $C_{\mathrm{ext}}$ poly $=N_{1} \times C_{\mathrm{ext}}\left(d_{\mathrm{g} 1}, \sigma_{\mathrm{g} 1}\right)+N_{2} \times C_{\mathrm{ext}}\left(d_{\mathrm{g} 2}, \sigma_{\mathrm{g} 2}\right)$. The PSL extinction coefficients were calculated using the BHMIE code (Bohren and Huffman, 1983) for $\lambda=630 \mathrm{~nm}$ and a refractive index of $1.585+0.0 i$. Finally, the extinction coefficient $\sigma_{\text {ep, poly }}$ was obtained by $\sigma_{\text {ep, poly }}=N_{\text {total }}$ $\times C_{\text {ext, poly }}$. Calculating the extinction coefficient of the polydisperse aerosol from normalized size distributions has the advantage of a direct comparison of extinction cross sections for monodisperse and polydisperse calibration aerosols, which provides a measure for the uncertainty introduced into the calibration procedure by the simplified assumption of single-sized PSL spheres.

Figure 4 shows number size distributions measured for the indicated PSL standards. Although the size distributions are dominated by the nominal PSL sphere mode, PSL conglomerates were observed. Input data to the Mie calculations

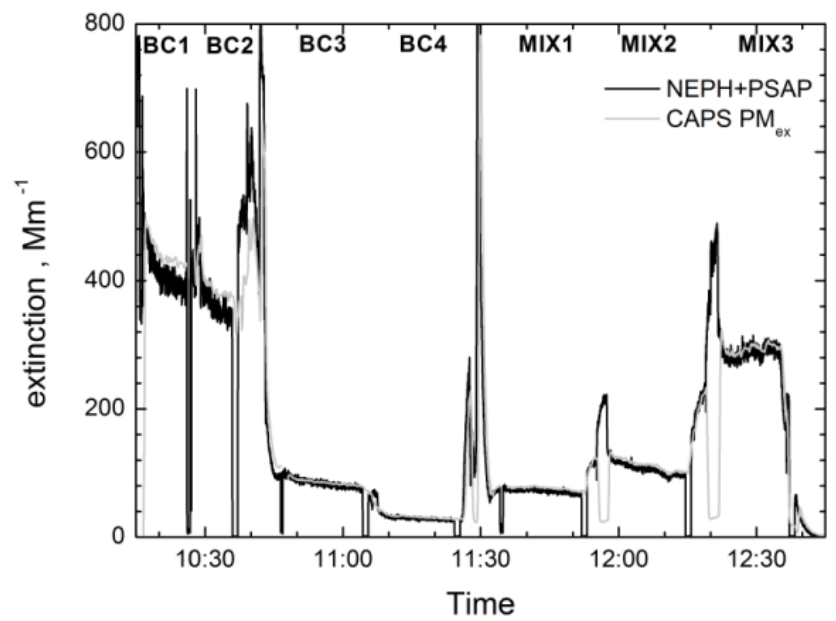

Fig. 6. Time series of CAPS $\mathrm{PM}_{\mathrm{ex}}$ extinction (black) and $\mathrm{NEPH}+\mathrm{PSAP}$ extinction (grey) for the laboratory-generated polydisperse $\mathrm{BC}$ and mixed $\mathrm{AS}+\mathrm{BC}$ experiments; analyzed sequences are labeled at the top $\mathrm{x}$-axis.

and results of the instrument calibration are compiled in Table 2. Calculated values for $C_{\mathrm{ext}}$, mono and $C_{\mathrm{ext}}$, poly deviate by $-8.33 \%(350 \mathrm{~nm}), 3.41 \%(499 \mathrm{~nm}),-1.82 \%(596 \mathrm{~nm})$ , $23.40 \%(701 \mathrm{~nm})$, and $6.80 \%(903 \mathrm{~nm})$, i.e. the simplified and the advanced approach show no systematic differences, though they differ statistically.

Correlation plots comparing extinction as calculated by Mie theory and extinction as measured by CAPS PM $_{\mathrm{ex}}$ are shown in Fig. 5. CAPS $\mathrm{PM}_{\mathrm{ex}}$ data were averaged over 35 min sequences after the aerosol generator output had stabilized sufficiently. Error bars in Fig. 5 correspond to $1-\sigma$ of the sequence average. Results of the respective linear regression analyses are inserted in the graphs. In both cases measured and calculated extinction coefficients are highly correlated with $R^{2}>0.98$. The slopes of regression lines are 0.96 (polydisperse) and 0.95 (monodisperse) with the differences being below statistical significance.

These PSL sphere experiments prove the excellent correlation between CAPS $\mathrm{PM}_{\mathrm{ex}}$ extinction monitor response and calculated extinction coefficients. Both approaches of using either the nominal PSL sphere size and the total number concentration or the full size distribution information for calculating the expected extinction coefficients agree well. These results indicate that the original gas phase-based pathlength adjustment measurement, included in the CAPS PM ex data acquisition software, was low by $5 \%$. As a consequence, CAPS $\mathrm{PM}_{\mathrm{ex}}$ data for this instrument evaluation using laboratory-generated polydisperse test aerosols and for the intercomparison purposes based on ambient aerosol data were corrected for the new pathlength adjustment by multiplication with a factor of 1.05 .

It has to be noted that the factor of 1.05 arises from a pathlength adjustment conducted for a single instrument. 
Table 2. Data used for the pathlength adjustment of CAPS $\mathrm{PM}_{\mathrm{ex}} *$

\begin{tabular}{|c|c|c|c|c|c|c|c|c|c|c|c|c|c|c|c|c|c|}
\hline \multicolumn{2}{|c|}{$\begin{array}{c}\text { PSL } \\
d_{\mathrm{p}, \text { nom }}, \mathrm{nm}\end{array}$} & \multicolumn{2}{|c|}{$\begin{array}{c}\text { Sequence } \\
N_{\text {total }}, \mathrm{cm}^{-3}\end{array}$} & \multirow[t]{2}{*}{$\begin{array}{r}\text { Mie }- \\
C_{\text {ext, mono, }}, \\
10^{-9} \mathrm{~cm}^{2}\end{array}$} & \multicolumn{2}{|c|}{$\sigma_{\text {ep }, \text { mono }}, \mathrm{Mm}^{-1}$} & \multicolumn{6}{|c|}{ Parameter of normalized PSL size distribution } & \multirow[t]{2}{*}{$\begin{array}{l}\text { Mie - } \\
C_{\text {ext,poly, }} \\
10^{-9} \mathrm{~cm}^{2}\end{array}$} & \multicolumn{2}{|c|}{$\sigma_{\text {ep,poly }}, \mathrm{Mm}^{-1}$} & \multicolumn{2}{|c|}{$\begin{array}{l}\text { CAPS PM }_{\mathrm{ex}} \\
\sigma_{\mathrm{ep}}, \mathrm{Mm}^{-1}\end{array}$} \\
\hline mean & $1-\sigma$ & mean & $1-\sigma$ & & mean & $1-\sigma$ & $N_{1}$ & $d_{\mathrm{g} 1}, \mu \mathrm{m}$ & $\sigma_{\mathrm{g} 1}$ & $N_{2}$ & $d_{\mathrm{g} 2}, \mu \mathrm{m}$ & $\sigma_{\mathrm{g} 2}$ & & mean & $1-\sigma$ & mean & $1-\sigma$ \\
\hline 499 & 5 & 202 & 3.2 & 6.67 & 134.8 & 2.1 & 0.998 & 0.490 & 1.1 & 0.002 & 0.800 & 1.25 & 6.45 & 130.4 & 2.0 & 117 & 0.7 \\
\hline 499 & 5 & 86 & 0.5 & 6.67 & 57.3 & 0.3 & & & & & & & 6.45 & 55.4 & 0.3 & 51 & 0.2 \\
\hline 499 & 5 & 47 & 0.9 & 6.67 & 31.4 & 0.6 & & & & & & & 6.45 & 30.4 & 0.6 & 28 & 0.2 \\
\hline 350 & 7 & 1669 & 14.6 & 1.76 & 293.5 & 2.6 & 0.981 & 0.350 & 1.1 & 0.019 & 0.460 & 1.15 & 1.92 & 320.5 & 2.8 & 315 & 1.4 \\
\hline 350 & 7 & 928 & 10.4 & 1.76 & 163.1 & 1.8 & & & & & & & 1.92 & 178.1 & 2.0 & 167 & 0.9 \\
\hline 350 & 7 & 523 & 4.0 & 1.76 & 92.0 & 0.7 & & & & & & & 1.92 & 100.5 & 0.8 & 95 & 0.4 \\
\hline 903 & 9 & 48 & 0.3 & 22.0 & 105.9 & 0.7 & 1.000 & 0.850 & 1.2 & 0.000 & 1.0 & 1.2 & 20.6 & 99.2 & 0.7 & 90 & 0.4 \\
\hline 903 & 9 & 27 & 0.3 & 22.0 & 58.8 & 0.7 & & & & & & & 20.6 & 55.0 & 0.7 & 52 & 0.4 \\
\hline 701 & 6 & 214 & 2.1 & 17.4 & 372.7 & 3.6 & 0.813 & 0.62 & 1.1 & 0.188 & 0.85 & 1.2 & 14.1 & 301.5 & 2.9 & 330 & 1.4 \\
\hline 701 & 6 & 103 & 0.6 & 17.4 & 179.0 & 1.1 & & & & & & & 14.1 & 144.8 & 0.9 & 161 & 0.6 \\
\hline 701 & 6 & 50 & 0.5 & 17.4 & 87.5 & 0.8 & & & & & & & 14.1 & 70.8 & 0.6 & 81 & 0.4 \\
\hline 596 & 6 & 456 & 4.5 & 10.8 & 490.0 & 4.9 & 0.867 & 0.57 & 1.1 & 0.133 & 0.7 & 1.2 & 11.0 & 500.2 & 5.0 & 455 & 2.1 \\
\hline 596 & 6 & 315 & 1.2 & 10.8 & 339.0 & 1.3 & & & & & & & 11.0 & 346.0 & 1.3 & 321 & 0.8 \\
\hline 596 & 6 & 105 & 0.8 & 10.8 & 112.8 & 0.8 & & & & & & & 11.0 & 115.2 & 0.8 & 108 & 0.4 \\
\hline
\end{tabular}

* Column content from left to right: nominal diameter of the PSL standard, $d_{\mathrm{p}, \text { nom }}$; average total number concentration of PSL spheres, $N_{\text {total }}$; extinction cross section, $C_{\text {ext, mono }}$, for monodisperse PSL spheres at diameter $d_{\mathrm{p}, \text { nom }}$; extinction coefficient calculated for monodisperse aerosol, $\sigma_{\mathrm{ep}}$, mono; parameters of normalized bimodal

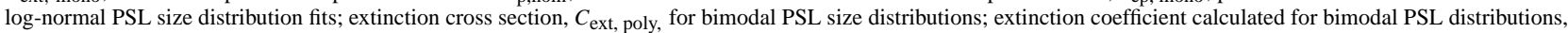

$\sigma_{\mathrm{ep}}$, poly; extinction coefficient measured by CAPS PM $\mathrm{ex}_{\mathrm{ep}}, \sigma_{\mathrm{ep}}$. Data are reported as mean value (mean) and 1- $\sigma$ standard deviation of the mean.

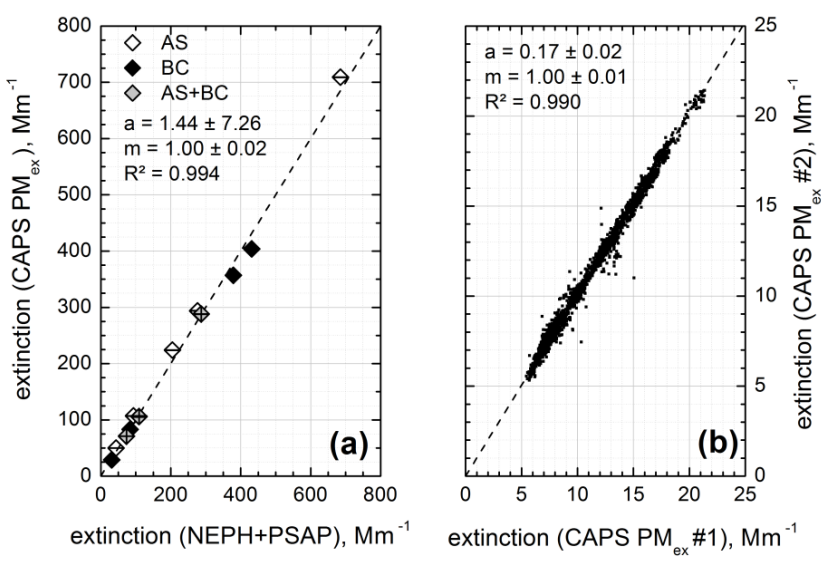

Fig. 7. (a) Accuracy: intercomparison of extinction measured by CAPS $\mathrm{PM}_{\mathrm{ex}}$ and extinction obtained from the combined $\mathrm{NEPH}+\mathrm{PSAP}$ analysis for polydisperse laboratory aerosols; all data refer to a wavelength of $630 \mathrm{~nm}$ and the error bars indicate $1-\sigma$ of the mean for respective averaging periods. (b) Precision: intercomparison of two CAPS PM $\mathrm{ex}_{\mathrm{e}}$ monitors operated side-by-side while sampling from laboratory air at temperature-controlled and dry conditions with $15 \mathrm{~s}$ time resolution. The dashed lines represent the $1: 1$ ratio.

However, data for two instruments run side-by-side as shown in the following section yield a slope of the regression line of unity (see Fig. 7a) and provide evidence that the pathlength correction is similar for all instruments. Because CAPS $\mathrm{PM}_{\mathrm{ex}}$ instruments now include the $5 \%$ pathlength adjustment to the reported results, users do not have to apply a further correction.

\subsection{Instrument evaluation using test aerosols}

As an illustration of the laboratory intercomparison studies, Fig. 6 shows a time series of the extinction coefficients measured during the $\mathrm{BC}+\mathrm{AS}$ test aerosol runs. A similar time series exists for pure AS aerosol which, however, is not shown here. The analysis of the CAPS PM $\mathrm{Px}_{\mathrm{e}}$ data and the combined NEPH + PSAP data was restricted to sequences of relatively stable aerosol concentrations. Table 3 compiles the data obtained from the averaging sequences of the various test aerosols. As indicated by the SSA values listed in Table 3 , the instrument evaluation covered the value range from 0.35 to 1.00 with test points at $0.81,0.89$, and 0.96 . Thus, the entire SSA range relevant for ambient aerosol measurements is covered by the generated test aerosols.

The ratio of $\sigma_{\mathrm{ep}}\left(\mathrm{CAPS} \mathrm{PM}_{\mathrm{ex}}\right)$ to $\sigma_{\mathrm{ep}}(\mathrm{NEPH}+\mathrm{PSAP})$ is listed in the rightmost column of Table 3; see also Fig. 12 for illustration. Due to the limited number of data points we analyzed the median instead of mean values for the respective test aerosols and obtained 1.09 for AS, 0.94 for BC, and 0.97 for the mixed cases. For the entire set of 12 data pairs the median ratio is 0.997 , while the respective mean and $1-\sigma$ values of the distribution are $1.018 \pm 0.074$.

Figure $7 \mathrm{a}$ displays the instrument evaluation data set graphically demonstrating the excellent accuracy of the CAPS PM $_{\mathrm{ex}}$ instrument determined by comparison to the $\mathrm{NEPH}+\mathrm{PSAP}$ combination. Linear regression analysis of the entire data set $(n=12)$ yields a slope $m=1.005 \pm 0.025$ if the zero intercept is set to 0.0 , and $m=1.002 \pm 0.02$ with zero intercept $a=1.44 \pm 7.26$. For both cases the correlation coefficient is $R^{2}>0.99$. Figure $7 \mathrm{~b}$ shows a correlation plot of data obtained from the side-by-side operation of two different CAPS $\mathrm{PM}_{\mathrm{ex}}$ monitors (operating at $530 \mathrm{~nm}$ ), both of 
Table 3. Data used for the evaluation of CAPS PMex with laboratory-generated polydisperse test aerosols: AS, BC, and mixed AS + BC*.

\begin{tabular}{|c|c|c|c|c|c|c|c|c|c|}
\hline \multirow[t]{2}{*}{$\begin{array}{r}\text { Run } \\
\text { ID }\end{array}$} & \multirow[t]{2}{*}{$\begin{array}{l}\text { Sequence } \\
\text { time }\end{array}$} & \multirow[t]{2}{*}{$\begin{array}{r}\text { correction** } \\
\mathrm{NEPH}\end{array}$} & \multicolumn{2}{|c|}{$\begin{array}{c}\sigma_{\mathrm{ep}}(630 \mathrm{~nm})^{* * *} \\
\mathrm{NEPH}+\mathrm{PSAP}\end{array}$} & \multirow{2}{*}{$\begin{array}{c}\begin{array}{c}\text { Ext. Ångström } \\
(467 / 630)\end{array} \\
\text { mean }\end{array}$} & \multirow{2}{*}{$\begin{array}{c}\begin{array}{c}\omega_{0} \\
(630 \mathrm{~nm})\end{array} \\
\text { mean }\end{array}$} & \multicolumn{2}{|c|}{$\begin{array}{c}\sigma_{\mathrm{ep}}(630 \mathrm{~nm})^{* * * * *} \\
\text { CAPS PM } \\
\text { CAx }\end{array}$} & \multirow[t]{2}{*}{$\begin{array}{l}\text { CAPS PM } \text { Px }_{\text {ex }} / \\
\text { NEPH + PSAP }\end{array}$} \\
\hline & & & mean & $1-\sigma$ & & & mean & $1-\sigma$ & \\
\hline AS1 & $14: 06-14: 34$ & AO98 & 685 & 1.0 & 2.07 & 1.010 & 709 & 0.3 & 1.03 \\
\hline AS2 & $14: 45-15: 00$ & AO98 & 277 & 0.5 & 2.23 & 1.012 & 294 & 0.2 & 1.06 \\
\hline AS3 & $15: 23-15: 36$ & AO98 & 205 & 0.4 & 2.11 & 1.013 & 224 & 0.1 & 1.09 \\
\hline AS4 & $15: 50-16: 10$ & AO98 & 44 & 0.2 & 1.53 & 1.015 & 50 & 0.1 & 1.13 \\
\hline AS5 & $16: 20-16: 40$ & AO98 & 94 & 0.2 & 1.50 & 1.014 & 107 & 0.1 & 1.14 \\
\hline $\mathrm{BC} 1$ & 10:18-10:26 & MA09 & 431 & 1.8 & 0.95 & 0.349 & 404 & 0.9 & 0.94 \\
\hline $\mathrm{BC} 2$ & $10: 30-10: 35: 30$ & MA09 & 379 & 1.5 & 0.97 & 0.349 & 357 & 0.8 & 0.94 \\
\hline $\mathrm{BC} 3$ & $10: 49-11: 04$ & MA09 & 84 & 0.3 & 1.02 & 0.360 & 83 & 0.2 & 0.99 \\
\hline $\mathrm{BC} 4$ & 11:09-11:24 & MA09 & 31 & 0.4 & 1.03 & 0.344 & 29 & 0.1 & 0.94 \\
\hline MIX1 & $11: 37-11: 51$ & AO98 & 73 & 0.2 & 2.66 & 0.811 & 71 & 0.1 & 0.97 \\
\hline MIX2 & 11:59-12:14 & AO98 & 109 & 0.8 & 2.96 & 0.889 & 106 & 1.0 & 0.97 \\
\hline MIX3 & $12: 24-12: 35$ & AO98 & 287 & 0.7 & 2.98 & 0.957 & 288 & 0.4 & 1.00 \\
\hline
\end{tabular}

* $\sigma_{\text {ep }}$ data are reported as mean value (mean) and 1- $\sigma$ standard deviation of the mean, averaged over the sequences of constant $\sigma_{\mathrm{ep}}$; all data refer to NEPH temperature and pressure conditions. ** NEPH correction schemes: AO98 $=$ (Anderson and Ogren, 1998); MA09 = (Massoli et al., 2009). *** NEPH + PSAP data were adjusted for a wavelength of $630 \mathrm{~nm}$ by applying the measured extinction Ångström exponent. **** CAPS PM $\mathrm{ex}_{\mathrm{ex}}$ data were multiplied by the pathlength adjustment factor 1.05 .
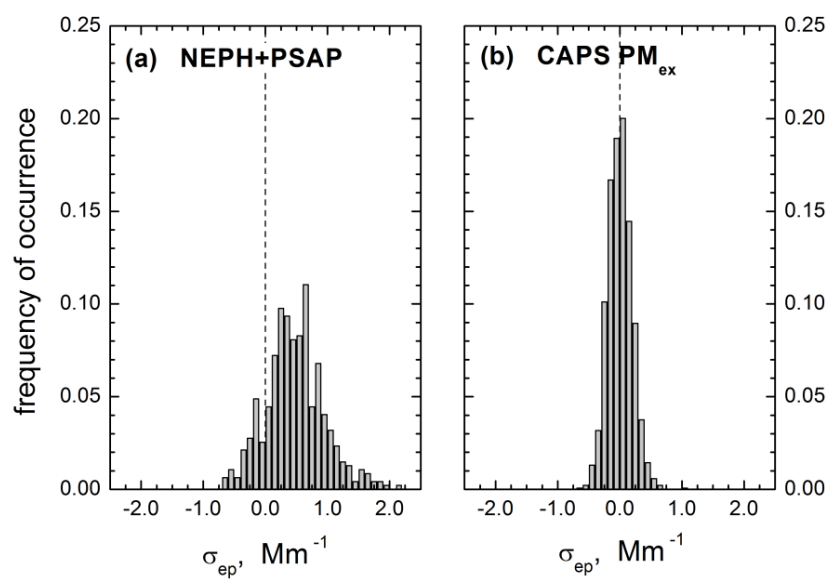

Fig. 8. Histograms of the electronic noise of NEPH+PSAP (left

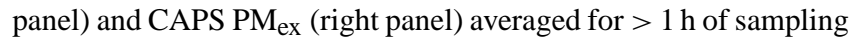
particle-free air.

which sampled temperature-controlled and dry laboratory air from a common inlet. The least squares fit to this data yield a slope of $1.00 \pm 0.01$ with zero intercept $a=0.17 \pm 0026$ and $R^{2}=0.990$, which provides an indication of the repeatability

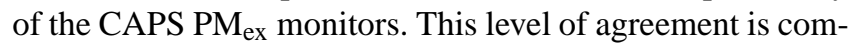
parable to that obtained using a monochromatic, laser-based cavity ring-down system (Massoli et al., 2010).

The relative precision of the CAPS $\mathrm{PM}_{\mathrm{ex}}$ monitor and NEPH+PSAP combination is shown in Fig. 8 as the histogram of data reported by the instruments during $1 \mathrm{~h}$ of sampling of particle-free air. The CAPS PM $_{\mathrm{ex}}$ instrument reports $\sigma_{\text {ep,zero }}=-0.25 \pm 0.91 \mathrm{Mm}^{-1}$ and $-0.004 \pm 0.19 \mathrm{Mm}^{-1}$ on average for 1 and $10 \mathrm{~s}$ data respectively, in agreement with previous studies (Massoli et al., 2010). The NEPH + PSAP combination yields $\sigma_{\text {ep, zero }}=0.473 \pm 0.471 \mathrm{Mm}^{-1}$ on average for $10 \mathrm{~s}$ data. The small offset is statistically insignificant.

Summarizing the results from instrument accuracy and precision studies, CAPS $\mathrm{PM}_{\mathrm{ex}}$ is characterized by detection limits of 2.5 and $0.6 \mathrm{Mm}^{-1}$ for averaging times of 1 and $10 \mathrm{~s}$, respectively, based on 3- $\sigma$ of the blank value fluctuation, and a reproducibility of $3 \%$ based on $3-\sigma$ of the linear regression slope uncertainty. Accuracy studies using PSL spheres yield an uncertainty of $\pm 1 \%$, which is of similar order as the value of $\pm 3 \%$ reported by Massoli et al. (2010). The level of uncertainty of $\pm 7 \%(3-\sigma)$ obtained for the test aerosol already includes potential uncertainties originating from the inversion of NEPH + PSAP data and will thus be beyond the upper limit of the CAPS $\mathrm{PM}_{\mathrm{ex}}$ uncertainty level which we determine as $\pm 3 \%$ in accordance with Massoli et al. (2010).

\subsection{Method intercomparison for ambient aerosol}

The first week of a two-week period for sampling of ambient aerosol (27 May to 8 June 2011) was characterized by a hot and humid stagnant high-pressure situation with reduced air mass exchange and thus fostered air pollution accumulation. During this initial episode, temperatures exceeded $35^{\circ} \mathrm{C}$ quite frequently. In the night from 2 to 3 June 2011 (ordinal day 153-154), a severe thunderstorm passed the area associated with high winds and heavy precipitation. After the passage of the frontal system, the pollution level was significantly reduced. Figure 9 shows the respective time series of various aerosol optical properties measured by the applied suite of instruments. In addition to the integral optical properties, Fig. 10 shows two examples of volume size distributions measured during the high and moderate pollution episodes, respectively, by the OPC. We applied the manufacturer's calibration for PSL spheres and assumed particle sphericity for 

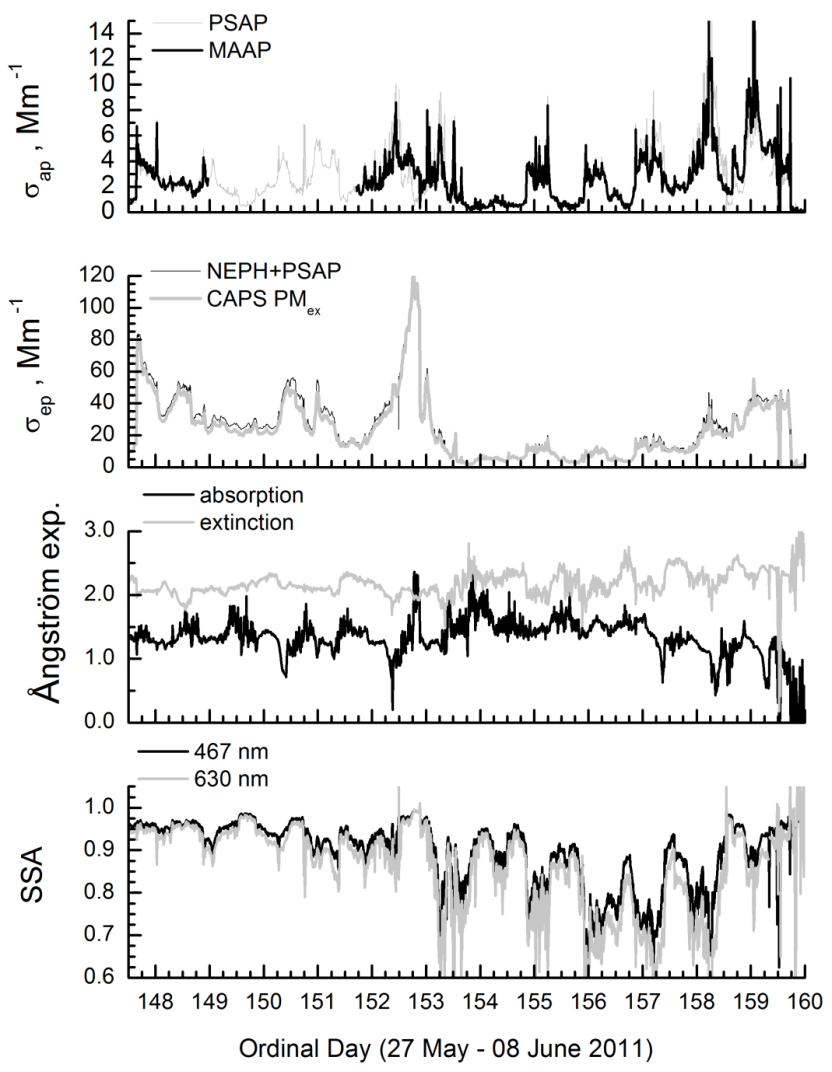

Fig. 9. Time series of aerosol optical properties at $\lambda=630 \mathrm{~nm}$ measured for ambient aerosol at Aerodyne Research Inc. premises. Properties are absorption coefficient, $\sigma_{\mathrm{ap}}$, from MAAP and PSAP; extinction coefficient, $\sigma_{\mathrm{ep}}$, from CAPS $\mathrm{PM}_{\mathrm{ex}}$ and $\mathrm{NEPH}+\mathrm{PSAP}$; Ångström exponents of extinction and absorption for the wavelength ratio $467 / 630 \mathrm{~nm}$; and single-scattering albedo, SSA, for wavelengths 467 and $630 \mathrm{~nm}$.

the conversion of number into volume size distributions since the size information is used only in a qualitative way.

In Episode 1 (27 May-2 June), the aerosol was characterized by high SSA values well above 0.90 at $630 \mathrm{~m}$ and the volume size distribution was dominated by large accumulation mode particles with a modal diameter of approx. $0.325 \mu \mathrm{m}$. In Episode 2 (3-8 June) the aerosol pollution was significantly reduced and the aerosol showed a strong diurnal variation pattern dominated by traffic-related emissions from the nearby highway. Respective SSA values at $630 \mathrm{~nm}$ varied between 0.66 at traffic peak time in the morning and 0.95 in the afternoon and evening hours. The modal diameter of the volume size distribution appeared to be below the lower detection limit of the optical particle counter of $0.25 \mu \mathrm{m}$. The coarse mode with its modal diameter of about $1.0 \mu \mathrm{m}$ was only moderately affected by the aerosol accumulated during the high pollution event.

Nighttime data for RH as recorded by the NEPH RH sensor were $<50 \%$ while peak RH data were $>80 \%$ at the end of Episode 1 before the thunderstorm passage and be-

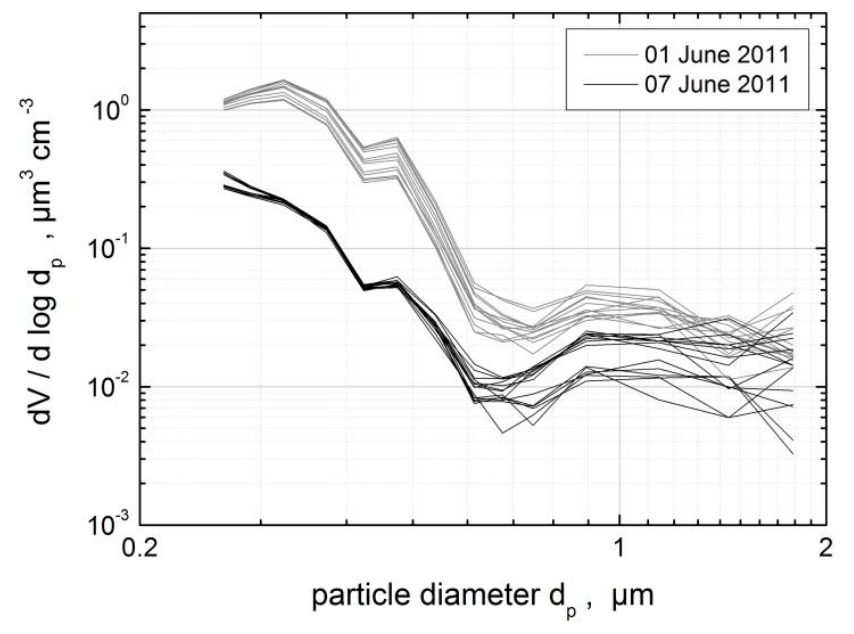

Fig. 10. Volume size distributions for 1 June (high pollution sequence; ordinal day 152) and 7 June (moderate pollution sequence; ordinal day 158) calculated from OPC size distributions.

low $60 \%$ during Episode 2 . The sequence where NEPH measured $\mathrm{RH}>70 \%$ is not included in the comparative analysis as these high RH conditions may affect the particle sampling due to condensation in the lines and may independently affect the measurements by the two instruments, which had slightly different internal temperatures $(\sim 2 \mathrm{~K})$. The analyzed data set consists of NEPH measured RH conditions less than $70 \%$.

The performance of the deployed instruments for the measurement of aerosol extinction (CAPS PM $\mathrm{Px}_{\mathrm{ex}}$, $\mathrm{NEPH}+\mathrm{PSAP}$ ) is shown in Fig. 11. Extinction coefficient data are highly correlated with $R^{2}>0.994$ for both analyzed data sets and respective regression line slopes of $0.95 \pm 0.01(a=0.98 \pm 0.12)$ for Episode 1 and $0.94 \pm 0.01$ $(a=0.07 \pm 0.04)$ for Episode 2. Similar results are reported from a recent study operating one CAPS PM $\mathrm{Px}_{\mathrm{ex}}$ and a NEPH + PSAP combination in the Storm Peak Laboratory, USA (Andrews et al., 2012). Potential reasons for the observed disagreement between CAPS $\mathrm{PM}_{\mathrm{ex}}$ and $\mathrm{NEPH}+\mathrm{PSAP}$ in case of ambient aerosol sampling are discussed in the following section.

The ratio of CAPS $\mathrm{PM}_{\mathrm{ex}}$ to NEPH + PSAP data is plotted in Fig. 12 for all investigated aerosol types. This graph illustrates an apparent discrepancy between the CAPS PM ex $_{\text {}}$ and the NEPH + PSAP extinction measurements for ambient data; the CAPS $\mathrm{PM}_{\mathrm{ex}}$ is approximately $5 \%$ low compared to NEPH + PSAP, with the bulk of data falling in the range 0.90-1.05. More important, however, is the observation that the scatter in the ratio $\sigma_{\mathrm{ep}}\left(\mathrm{CAPS} \mathrm{PM}_{\mathrm{ex}}\right) / \sigma_{\mathrm{ep}}$ $(\mathrm{NEPH}+\mathrm{PSAP})$ is randomly distributed instead of being in correlation to the absolute value of $\sigma_{\mathrm{ep}}$; e.g. for high extinction levels of $300 \mathrm{Mm}^{-1}$, the ratio of CAPS PM $\mathrm{NEPH}+\mathrm{PSAP}$ is 0.94 for absorbing aerosol, 1.00 for mixed aerosol, and 1.06 for pure AS. Respective numbers for an extinction level of approx. $100 \mathrm{Mm}^{-1}$ are 0.99 (BC), 0.97 


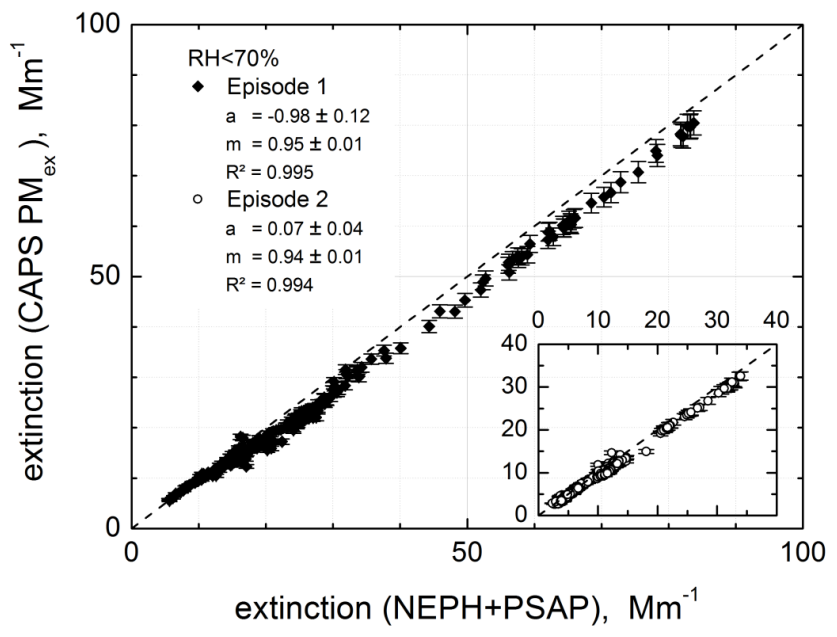

Fig. 11. Intercomparison of extinction measured by CAPS PM $\mathrm{Px}_{\mathrm{x}}$ and extinction obtained from the combined NEPH + PSAP analysis for ambient aerosols. The dashed lines represent the $1: 1$ relation and errors bars indicate the $\pm 3 \%$ uncertainty range of CAPS PM data.

(MIX), and 1.14 (AS). In total there is no link between the extinction level and the ratio of CAPS $\mathrm{PM}_{\mathrm{ex}}$ to NEPH+PSAP observed.

\section{Discussion and conclusions}

The results from the instrument calibration work with PSL spheres and Mie theory yield a strong correlation $\left(R^{2}>0.98\right)$ between instrument response and light extinction calculated by Mie theory. The particle-based measurements indicate a pathlength adjustment of 1.05 compared to previous gas phase-based estimates. The new pathlength adjustment factor agrees with instrument geometry. With this one-time adjust-

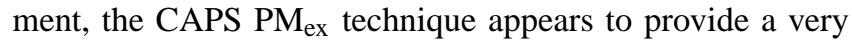
accurate measurement of aerosol light extinction.

Instrument evaluation of CAPS $\mathrm{PM}_{\mathrm{ex}}$ versus the NEPH + PSAP combination using highly absorbing black carbon particles (Regal black), exclusively scattering aerosol (ammonium sulfate) and mixtures of both show excellent correlation between methods. The slope of the regression line is 0.99 , demonstrating the robustness of the calibration for aerosol particles with single scattering albedos ranging from strongly absorbing with $\mathrm{SSA}=0.35$ to purely scattering with $\mathrm{SSA}=1.0$.

This instrument intercomparison between the CAPS PM $\mathrm{ex}_{\mathrm{x}}$ and the widely used method of NEPH + PSAP combination for ambient aerosol sampled from a rooftop inlet serves as realistic test case for the measurement of ambient aerosol under field conditions. The bulk of the CAPS PM $_{\mathrm{ex}}$ data deviate from respective NEPH + PSAP data by $-5 \%$, indicating a small but robust disagreement which is not present for the

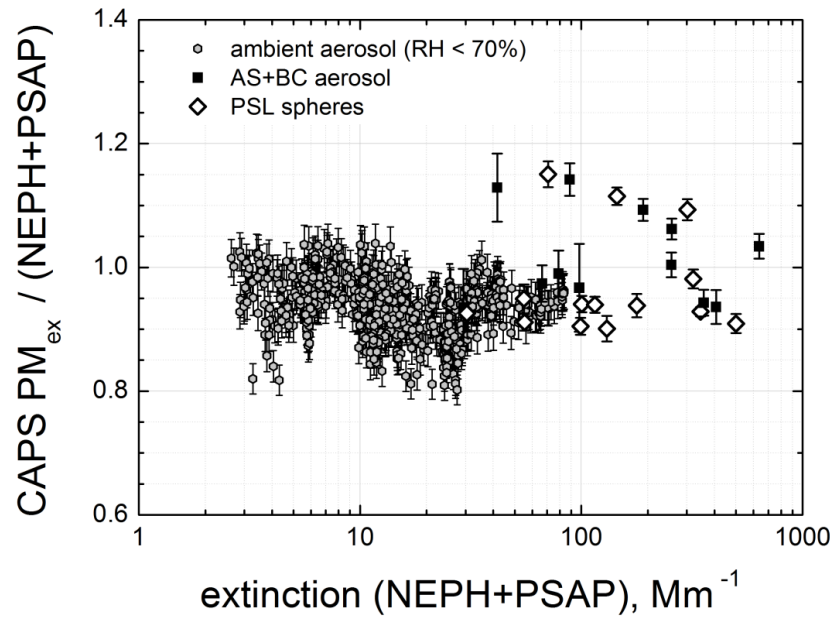

Fig. 12. Ratio of extinction reported by CAPS $\mathrm{PM}_{\mathrm{ex}}$ to extinction calculated from NEPH + PSAP for the entire range of extinction coefficients measured for laboratory and ambient aerosols. Ambient aerosol data are $10 \mathrm{~min}$ average values with its error bars indicating the $\pm 3 \%$ uncertainty range of CAPS PM $\mathrm{Px}_{\mathrm{ex}}$ data; error bars of test aerosol data refer to the $1-\sigma$ of the mean for respective averaging periods.

laboratory studies. There are a number of possible explanations for this small level of disagreement:

1. The observed temperature difference of approx. $2 \mathrm{~K}$ between CAPS PM $\mathrm{ex}_{\mathrm{x}}$ and NEPH implies a potential RH difference between the two instruments of $\sim 13 \%$, with the CAPS PM $\mathrm{Px}_{\mathrm{ex}}$ instrument experiencing a higher maximum RH of $\sim 83 \%$. Assuming ammonium sulfate particles, this RH difference could potentially lead to significant differences between the extinction measurements of the two techniques with the CAPS $\mathrm{PM}_{\mathrm{ex}}$ theoretically measuring higher extinctions, which were not observed. Typical particle compositions measured at the measurements site (i.e. Aerodyne Research, Inc., Billerica, MA), though conducted separately and at different times, indicate that the particles are composed primarily of organics, which will have significantly reduced hygroscopicity changes under these RH conditions. Finally, the observed differences in measured extinction between the two instruments indicate that the NEPH + PSAP extinctions were, on average, slightly higher than the CAPS $\mathrm{PM}_{\mathrm{ex}}$ extinctions (see Fig. 12), which is in the opposite direction of any potential impact due to the temperature and $\mathrm{RH}$ differences between the two instruments.

2. The observed disagreement can potentially be explained by an enhanced absorption measurement caused by organic coatings on the filter of the PSAP; see e.g. Cappa et al. (2008) and Lack et al. (2008). An average ratio of $\sigma_{\text {ep }}\left(\mathrm{CAPS} \mathrm{PM}_{\mathrm{ex}}\right) / \sigma_{\mathrm{ep}}(\mathrm{NEPH}+\mathrm{PSAP})$ of 0.95 for the presented set of ambient data would require an 
overestimation of $\sigma_{\text {ap }}$ by approx. $25 \%$ for the observed SSA level of 0.80 which falls well into the range of overestimations of PSAP absorption data compared to photoacoustic spectroscopy data reported by Lack et al. (2008).

3. Another possibility is that the truncation correction for the NEPH is more uncertain for particles of diameter greater than $1 \mu \mathrm{m}$, the largest diameter sampled in the laboratory studies.

A comprehensive assessment of potential errors in determining aerosol optical properties from various instrument combinations is beyond the scope of this publication and will be addressed in an ongoing follow-up study.

Acknowledgements. This study was conducted during a research stay of A. Petzold at Aerodyne Research Inc. in 2011 when he was employed by Deutsches Zentrum für Luft- und Raumfahrt (DLR). The support of this secondment by DLR is gratefully acknowledged. The authors thank A. Ibrahim (DLR) for his valuable contributions during the measurement periods. The provision of the $\mathrm{PM}_{10}$ sampling head for the ambient aerosol sampling line by Thermo Fischer is gratefully acknowledged. The efforts of the Aerodyne personnel were supported by the US Department of Energy, NASA and the National Institutes of Health, all under the Small Business Innovation Research program.

The service charges for this open access publication have been covered by a Research Centre of the Helmholtz Association.

Edited by: D. Toohey

\section{References}

Anderson, T. L. and Ogren, J. A.: Determining aerosol radiative properties using the TSI 3563 integrating nephelometer, Aerosol Sci. Technol., 29, 57-69, 1998.

Andrews, E., Massoli, P., Hallar, A. G., Sedlacek, A., Freedman, A., Ogren, J. A., and Sheridan, P.: Absorption closure - filter-based absorption instruments compared to extinction-scattering measurements, European Aerosol Conference, Granada Spain, 2-7 September, 2012.

Arnott, W. P., Moosmüller, H., Sheridan, P. J., Ogren, J. A., Raspet, R., Slaton, W. V., Hand, J. L., Kreidenweis, S. M., and Collett, J. L. J.: Photoacoustic and filter-based ambient aerosol light absorption measurements: Instrument comparisons and the role of relative humidity, J. Geophys. Res., 108, 4034, doi:10.1029/2002JD002165, 2003.

Atkinson, D. B., Massoli, P., O’Neill, N. T., Quinn, P. K., Brooks, S. D., and Lefer, B.: Comparison of in situ and columnar aerosol spectral measurements during TexAQS-GoMACCS 2006: testing parameterizations for estimating aerosol fine mode properties, Atmos. Chem. Phys., 10, 51-61, doi:10.5194/acp-10-512010, 2010.

Baynard, T., Pettersson, A., Lovejoy, E. R., Brown, S. S., Lack, D. A., Massoli, P., Osthoff, H., Ciciora, S., Dube, W. P., and Ravis- hankara, A. R.: Design and application of a pulsed cavity ringdown aerosol extinction spectrometer for field measurements, Aerosol Sci. Technol., 41, 447-462, 2007.

Bohren, C. F. and Huffman, D. R.: Absorption and Scattering of Light by Small Particles., John Wiley \& Sons, Inc, New York, 544 pp., 1983.

Bond, T. C., Anderson, T. L., and Campbell, D.: Calibration and Intercomparison of Filter-Based Measurements of Visible Light Absorption by Aerosols, Aerosol Sci. Technol., 30, 582-600, 1999.

Butler, T. J. A., Mellon, D., Kim, J., Litman, J., and Orr-Ewing, A. J.: Optical-Feedback Cavity Ring-Down Spectroscopy Measurements of Extinction by Aerosol Particles, J. Phys. Chem. A, 113, 3963-3972, doi:10.1021/jp810310b, 2009.

Cappa, C. D., Lack, D. A., Burkholder, J. B., and Ravishankara, A. R.: Bias in filter-based aerosol light absorption measurements due to organic aerosol loading: Evidence from laboratory measurements, Aerosol Sci. Technol., 42, 1022-1032, doi:10.1080/02786820802389285, 2008.

Chartier, R. T. and Greenslade, M. E.: Initial investigation of the wavelength dependence of optical properties measured with a new multi-pass Aerosol Extinction Differential Optical Absorption Spectrometer (AE-DOAS), Atmos. Meas. Tech., 5, 709-721, doi:10.5194/amt-5-709-2012, 2012.

Cross, E. S., Onasch, T. B., Ahern, A., Wrobel, W., Slowik, J. G., Olfert, J., Lack, D. A., Massoli, P., Cappa, C. D., Schwarz, J. P., Spackman, J. R., Fahey, D. W., Sedlacek, A., Trimborn, A., Jayne, J. T., Freedman, A., Williams, L. R., Ng, N. L., Mazzoleni, C., Dubey, M., Brem, B., Kok, G., Subramanian, R., Freitag, S., Clarke, A., Thornhill, D., Marr, L. C., Kolb, C. E., Worsnop, D. R., and Davidovits, P.: Soot Particle Studies-Instrument InterComparison-Project Overview, Aerosol Sci. Technol., 44, 592611, 2010.

Heintzenberg, J., Wiedensohler, A., Tuch, T. M., Covert, D. S., Sheridan, P., Ogren, J. A., Gras, J., Nessler, R., Kleefeld, C., Kalivitis, N., Aaltonen, V., Wilhelm, R. T., and Havlicek, M.: Intercomparisons and aerosol calibrations of 12 commercial integrating nephelometers of three manufacturers, J. Atmos. Ocean. Technol., 23, 902-914, 2006.

Hinds, W. C.: Aerosol Technology: Properties, Behaviour and Measurement of Airborne Particles., John Wiley \& Sons, Inc., New York, 483 pp., 1999.

Kebabian, P. L. and Freedman, A.: System and Method for Trace Species Detection Using Cavity Attenuated Phase Shift Spectroscopy with an Incoherent Light Source, US Patent No. 7301639 (issued 27 November 2007), 2007.

Kebabian, P. L., Robinson, W. A., and Freedman, A.: Optical extinction monitor using cw cavity enhanced detection, Rev. Sci. Instrum., 78, 063102, doi:10.1063/1.2744223, 2007.

Lack, D. A., Cappa, C. D., Covert, D. S., Baynard, T., Massoli, P., Sierau, B., Bates, T. S., Quinn, P. K., Lovejoy, E. R., and Ravishankara, A. R.: Bias in filter-based aerosol light absorption measurements due to organic aerosol loading: Evidence from ambient measurements, Aerosol Sci. Technol., 42, 1033-1041, doi:10.1080/02786820802389277, 2008.

Langridge, J. M., Richardson, M. S., Lack, D., Law, D., and Murphy, D. M.: Aircraft Instrument for Comprehensive Characterization of Aerosol Optical Properties, Part I: Wavelength-Dependent Optical Extinction and Its Relative Humidity Dependence 
Measured Using Cavity Ringdown Spectroscopy, Aerosol Sci. Technol., 45, 1305-1318, doi:10.1080/02786826.2011.592745, 2011.

Loeb, N. G. and Su, W. Y.: Direct Aerosol Radiative Forcing Uncertainty Based on a Radiative Perturbation Analysis, J. Climate, 23, 5288-5293, doi:10.1175/2010jcli3543.1, 2010.

Massoli, P., Murphy, D. M., Lack, D. A., Baynard, T., Brock, C. A., and Lovejoy, E. R.: Uncertainty in light scattering measurements by TSI Nephelometer: Results from Laboratory studies and implications for ambient measurements, Aerosol Sci. Technol., 43, 1064-1074, 2009.

Massoli, P., Kebabian, P. L., Onasch, T. B., Hills, F. B., and Freedman, A.: Aerosol Light Extinction Measurements by Cavity Attenuated Phase Shift (CAPS) Spectroscopy: Laboratory Validation and Field Deployment of a Compact Aerosol Particle Extinction Monitor, Aerosol Sci. Technol., 44, 428-435, doi:10.1080/02786821003716599, 2010.

Moosmüller, H., Varma, R., and Arnott, W. P.: Cavity ringdown and cavity-enhanced detection techniques for the measurement of aerosol extinction, Aerosol Sci. Technol., 39, 30-39, doi:10.1080/027868290903880, 2005.

Müller, T., Henzing, J. S., de Leeuw, G., Wiedensohler, A., Alastuey, A., Angelov, H., Bizjak, M., Collaud Coen, M., Engström, J. E., Gruening, C., Hillamo, R., Hoffer, A., Imre, K., Ivanow, P., Jennings, G., Sun, J. Y., Kalivitis, N., Karlsson, H., Komppula, M., Laj, P., Li, S.-M., Lunder, C., Marinoni, A., Martins dos Santos, S., Moerman, M., Nowak, A., Ogren, J. A., Petzold, A., Pichon, J. M., Rodriquez, S., Sharma, S., Sheridan, P. J., Teinilä, K., Tuch, T., Viana, M., Virkkula, A., Weingartner, E., Wilhelm, R., and Wang, Y. Q.: Characterization and intercomparison of aerosol absorption photometers: result of two intercomparison workshops, Atmos. Meas. Tech., 4, 245-268, doi:10.5194/amt-4-245-2011, 2011.

Ogren, J. A.: Comment on "Calibration and Intercomparison of Filter-Based Measurements of Visible Light Absorption by Aerosols", Aerosol Sci. Technol., 44, 589-591, 2010.

Petzold, A. and Schönlinner, M.: Multi-angle absorption photometry - A new method for the measurement of aerosol light absorption and atmospheric black carbon, J. Aerosol Sci., 35, 421-441, 2004.

Petzold, A., Schlösser, H., Sheridan, P. J., Arnott, W. P., Ogren, J. A., and Virkkula, A.: Evaluation of multiangle absorption photometry for measuring aerosol light absorption, Aerosol Sci. Technol., 39, 40-51, 2005.
Schmid, B., Ferrare, R., Flynn, C., Elleman, R., Covert, D., Strawa, A., Welton, E., Turner, D., Jonsson, H., Redemann, J., Eilers, J., Ricci, K., Hallar, A. G., Clayton, M., Michalsky, J., Smirnov, A., Holben, B., and Barnard, J.: How well do state-of-the-art techniques measuring the vertical profile of tropospheric aerosol extinction compare?, J. Geophys. Res.-Atmos., 111, D05S07, doi:10.1029/2005jd005837, 2006.

Schnaiter, M., Schmid, O., Petzold, A., Fritzsche, L., Klein, K. F., Andreae, M. O., Helas, G., Thielmann, A., Gimmler, M., Mohler, O., Linke, C., and Schurath, U.: Measurement of wavelengthresolved light absorption by aerosols utilizing a UV-VIS extinction cell, Aerosol Sci. Technol., 39, 249-260, 2005.

Schwartz, S. E., Charlson, R. J., Kahn, R. A., Ogren, J. A., and Rodhe, H.: Why Hasn't Earth Warmed as Much as Expected?, J. Climate, 23, 2453-2464, doi:10.1175/2009jcli3461.1, 2010.

Sheridan, P. J., Arnott, W. P., Ogren, J. A., Andrews, E., Atkinson, D. B., Covert, D. S., Moosmüller, H., Petzold, A., Schmid, B., Strawa, A. W., Varma, R., and Virkkula, A.: The Reno Aerosol Optics Study: An Evaluation of Aerosol Absorption Measurement Methods, Aerosol Sci. Technol., 39, 1-16, 2005.

Solomon, S., Qin, D., Manning, M., Chen, Z., Marquis, M., Averyt, K. B., Tignor, M., and Miller, H. L.: IPCC, 2007: Climate Change 2007: The Physical Science Basis. Contribution of Working Group I to the Fourth Assessment Report of IPCC, Cambridge University Press, Cambridge, United Kingdom and New York, NY, USA, 996 pp., 2007.

Strawa, A. W., Castaneda, R., Owano, T., Baer, D. S., and Paldus, B. A.: The measurement of aerosol optical properties using continuous wave cavity ring-down techniques, J. Atmos. Ocean. Technol., 20, 454-465, 2003.

Virkkula, A.: Correction of the Calibration of the 3-wavelength Particle Soot Absorption Photometer (3 PSAP), Aerosol Sci. Technol., 44, 706-712, doi:10.1080/02786826.2010.482110, 2010.

Virkkula, A., Ahlquist, N. C., Covert, D. S., Arnott, W. P., Sheridan, P. J., Quinn, P. K., and Coffman, D. J.: Modification, Calibration and a Field Test of an Instrument for Measuring Light Absorption by Particles, Aerosol Sci. Technol., 39, 68-83, 2005.

Yu, Z., Ziemba, L. D., Onasch, T. B., Herndon, S. C., Albo, S. E., Miake-Lye, R., Anderson, B. E., Kebabian, P. L., and Freedman, A.: Direct Measurement of Aircraft Engine Soot Emissions Using a Cavity-Attenuated Phase Shift (CAPS)-Based Extinction Monitor, Aerosol Sci. Technol., 45, 1319-1325, doi:10.1080/02786826.2011.592873, 2011. 